\title{
Teologie en etiek in die brief aan Filemon: 'n Poging tot verantwoording 1
}

J H Roberts

\section{ABSTRACT}

Theology and ethics in the letter to Philemon: An attempt at giving an account

The criticism levelled by Smit against the attempts of New Testament scholars to treat the ethics of the books of the New Testament are dealt with under the headings of "ethos and ethics"; "Biblical ethics"; "the tasks of New Testament ethics"; and "the teaching of the Bible". In order to give an account of the work done by New Testament scholars the ethics of Paul in the letter to Philemon is discussed. After a brief summary of the argument of Philemon, the request of this letter is analysed from the viewpoint of ethical argumentation, concluding with remarks on theology and ethics in Philemon.

INLEIDING

Die betreklik nuwe kommentaarreeks Kommentaar op die Nuwe Testament: Struktuur, uitleg, boodskap, waarvan as tweede volume Die brief aan Filemon teen die einde van 1992 verskyn het ${ }^{2}$, breek nuwe bane deur die strukturele elemente van die Nuwe-Testamentiese geskrifte te benut vir die uitleg daarvan - uiteraard in debat met die voorafgaande geskiedenis van die uitleg - en wil verder as resultaat van die eksegetiese werk die boodskap van die geskrif vir sy tyd en vandag probeer formuleer. Die rekenaardrukstuk van Die brief aan Filemon is vroeg in 1988 aan die redaksie besorg - in die tyd toe die Teologiese Fakulteit van die Nederduitse Gereformeerde Kerk aan die Universiteit van Pretoria sy vyftigste bestaansjaar feestelik herdenk het. Dit het ' $n$ goeie geleentheid gebied om my waardering vir die Fakulteit te betoon deur die werk daaraan op te dra. Dat die werk eers in 1992 kon verskyn, was aan verskeie faktore te wyte. Die vertraging in die verskyning maak die opdrag van die werk aan die Fakulteit vir my nie minder relevant of vreugdevol nie. Ek is bly oor die geleentheid om langs hierdie weg dankie te kan sê vir die vorming waarin ek kon deel, en ook, deur die betuiging van solidariteit met die huidige werk van die Fakulteit, vir die lede daarvan seën en sterkte toe te bid vir die opleidings- en navorsingswerk wat hier verrig word. My besondere dank veral aan die Nuwe-Testamentici vir kollegialiteit en kameraadskap wat oor baie jare saam beleef kon word. Dat ek om hierdie redes die boek aan u kon opdra en vandag aan u kon oorhandig verskaf my werklik diepe vreugde. Ek is uiteraard ook verheug dat ek by hierdie geleentheid met $u$ as kollegas en studente enkele gedagtes kan wissel. Dit is nie "n geringe saak dat ek vanuit die "sekulêre" sfeer van my eie fakulteit vanmôre hierdie "heilige sale" mog betree en in u deurlugtige geselskap my siening oor enkele aspekte van die 'teologie en etiek van Filemon mag lug nie. Ek dank u vit die geleentheid.

Die wyse waarop ek gemeen het om die genoemde tema aan te sny, hang 
saam met ' $n$ debat wat in 'n ander publikasie gevoer is. Teen die einde van 1992 het ' $n$ bundel artikels oor die etiek van 'n hele aantal Nuwe-Testamentiese boeke, geskryf deur Suid-Afrikaanse Nuwe-Testamentici, verskyn ${ }^{3}$. Die redaksie het die Wes-Kaaplandse sistematikus D J Smit versoek om in 'n afsluitende opstel 'n kritiese bespreking van die gebode artikels te lewer. In hierdie responsie het Smit enersyds baie waardering vir die analises wat deur die Nuwe-Testamentici gebied is, maar is andersyds van mening dat dit vir etici, en met name die benefenaars van die Christelike etiek, van geen betekenis is nie en geen bydrae lewer tot 'n gesprek tussen die twee dissiplines nie 4 . Smit se kritiek roep 'n baie ou stryd wat oor eeue heen tussen sistematici en Bybelwetenskaplikes gevoer is ${ }^{5}$, weer op die voorgrond. Te midde van die stryd het daar egter ook 'n groeiende bewussyn tot stand gekom van die onderlinge behoefte aan mekaar6. Ek weet van geen pittiger stelling van hierdie aangeleentheid as dié deur Herman Ridderbos by geleentheid van 'n rede gelewer voor' $n$ werkgemeenskap van dogmatici nie?:

Het is een verheugend verschijnsel - er is in de laatste tijd meermalen op gewezen! - dat de dogmatiek en de exegese steeds meer besef vertonen van een gemeenschappelijke verantwoordelijkheid. Dat dit wel eens anders geweest is, behoef ik $u$ niet te zeggen. Lange tijd heeft de exegese als huisslavin in het diensthuis van de dogmatiek gezucht. Zij maakte, als haar heer sliep, wel eens heimelijk uitstapjes, maar als in de morgen de hanen begonnen te kraaien, haastte zij zich in de regel weer op haar post te zijn. Dit heeft dergelijke traumata van minderwaardigheidsgevoelens achtergelaten, dat het lange tijd tot de goede stijl van de exegetische wetenschap heeft behoord om bij het noemen van de naam dogmatiek enige malen krachtig op de grond te spuwen ten bewijze van eigen flinkheid en zelfstandigheid. Zelfs is er een tijd geweest, die men dan misschien als de "opstand der horden" kan kwalificeren, waarin de exegese het zeer bepaald tot haar taak rekende het gehele ancienne régime onder haar valbijl te doen doorgaan.

Doch de dagen van de Sansculotten en Jacobijnen duren nooit lang. "Volstrekte boedelscheiding van dogmatiek en exegese" wordt daarna het parool. De historische school viert haar triomfen in de exegese. Zij betuigt niets, maar ook niets te willen veronderstellen of te willen impliceren in dogmatisch opzicht. Stijve buigingen van weerskanten van de straat zijn het enige bewijs dat men elkander nog kent. Men verhult de volstrekte breuk onder het schone woord van de "tweeërlei benadering". Een opgesplitste theologie, geestelijk scepticisme aan de ene kant, slechte gewetens aan de andere kant waren het gevolg. Uit deze impasse is toch iets nieuws gegroeid: het bewustzijn, dat het leven een eenheid is, dat de wetenschap ondeelbaar is, dat de exegese niet kan zeggen: dewijl ik het hart niet ben, behoor ik niet tot het lichaam en de dogmatiek niet kan beweren: dewijl ik mijn handen niet wil vuil maken, zal ik mij alleen maar pneumatisch bewegen. Dit nieuwe besef van gemeenschappelijke verantwoordelijkheid is een schone zaak. Maar wèl stelt zij zowel de dogmatiek als de exegese voor vragen, die men vroeger naar het departement van de buurman kon doorzenden, doch thans mee moeten helpen oplossen. 
Is hiermee die behoefte aan onderlinge gesprek, aan interdissiplinêre bevrugting en samewerking enigsins geillustreer, bly die verwyt van $\mathrm{Smit}^{8}$ dat die Nuwe-Testamentici wat hierdie poging oor die etiek van die Nuwe Testament aangepak het in 'n "huis van dowes" woon - horende doof vir die behoefte van ander teoloë se pleitstemme om te verstaan wat hulle doen en ernstig geneem te word in die gesprek, steeds roep om 'n antwoord. In my poging om daartoe by te dra, wil ek hieronder eers die argumente, die saak wat Smit aan die orde stel, in 'n aantal vrae probeer saamvat en daarop antwoord deur onder andere enkele opmerkings te maak oor wat die bundel artikels in die algemeen probeer verwoord; vervolgens my eie aanpak oor die brief aan Filemon in die bundel, met verwysing na die pas verskene kommentaar en 'n aantal van my ander publikasies oor Filemon', probeer verduidelik; om ten slotte die resultaat weer te gee in 'n bespreking van teologie en etiek in die brief aan Filemon.

\section{DIE ARGUMENTE VAN SMIT}

\section{$2.1 \quad$ Die vraag na etos en etiek}

Smit ${ }^{10}$ doen baie moeite om ons mooi te beleer oor wat etos is en wat etiek, asook die verskil tussen die twee begrippe. Etos is die manier waarop 'n groep mense hulle opvattings oor reg en verkeerd uitleef - dis hulle gemeenskaplike moraal. Etiek is die bewuste nadenke oor wat goed is of kwaad"1. In die kompleks van vrae rondom hierdie sake is dit baie belangriker om te weet hoe die Bybel mense se etos beïnvloed as hoe dit hulle etiek beïnvloed 12 . Die skrywers sou volgens hom waarskynlik nie eers interesse daarin hê om die openbare etos deur hulle werk te beïnvloed nie ${ }^{13}$. Die rede vir hierdie bespreking deur Smit, is dat hy meen die skrywers wil met hulle bydraes vir etici wys hoe hulle antwoorde uit die Bybel moet kry vir die morele vraagstukke van die huidige tyd. Hierin sou hulle dan geensins slaag nie omdat hulle nie al die faktore wat rondom etiese beslissings geld, in ag neem nie; ook omdat hulle nie in staat is om op 'n behoorlik wetenskaplike wyse die huidige situasie te ontleed nie; ook omdat hulle nie self besef hoe 'n ingewikkelde proses dit is on Skrifgegewens aanvaarbaar en oortuigend en sinvol in ' $n$ etiese argument te benut nie 14 ; en ook omdat die Bybel glad nie op al die moderne vrae 'n antwoord kan of wil bied nie.

Ek dink nie dit is die taak of die begeerte van Nuwe-Testamentici om die wetenskaplike etiek te beleer nie. Die artikels is dan ook sekerlik nie geskryf met die gedagte om direk bruikbaar te wees vir die etiek nie'15 - 'n gesprek kan ook'n ander betekenis hê! Die skrywers probeer nie etiek bedryf of 'n, of die etiek van die Nuwe Testament skryf nie. Nog minder probeer hulle die gegewens van die Nuwe Testament te benut vir die daarstel van 'n Bybelse of Christelike etiek.

Wat hierdie skrywers ter harte gaan, is om te probeer verstaan en om aan te toon hoe Bybelskrywers, deur doelbewuste nadenke, met morele vraagstukke van bepaalde Christelike gemeenskappe geworstel het omdat hulle hulle eksistensieel daarby betrokke geag het, en in dié sin dus eties besig was, etiek beoefen het, in ' $n$ poging om die etos van hulle lesers te verander. Dit gaan daarom om die proses te ontleed, om die gronde vir hulle standpunte te probeer vasstel, om die norme te verstaan waarmee hulle werk. Wanneer die Nuwe-Testamentikus self ook eksisten- 
sieel by dié tradisie betrokke is, daarom ook die kanon hoog ag, en eksistensieel by die morele vraagstukke van die Christelike gemeenskap betrokke is, moet daar nog een stap hierop volg: daar moet ook daaroor nagedink word of dié prosesse, dié gronde, dié norme vir ons as Christene van vandag nog iets te sê het.

Vir die nadenke oor hierdie aspekte is daar werklik geen gesofistikeerde analise van die huidige situasie nodig nie ${ }^{16}$. Ons skryf immers geen etiek nie! Die boeke wat ons afsonderlik ontleed het, was gemik op 'n spesifieke situasie of konteks waarvoor hulle 'n antwoord wou bied. Ons vraag is nou of hierdie antwoord vir daardie spesifieke situasie, ook êrens vir ons wat eksistensieel verbonde is aan die tradisie wat die teks verteenwoordig, iets te sê het met die oog op die eie situasie wat ons tans eksistensieel beleef. Wie meen dat dit 'n reglynige oordrag beteken van opdragte in die Bybelteks na die lewe van vandag, het nie goed geluister wat ons sê nie, het nie die ingewikkelde proses verstaan wat ons probeer volg het deur die boodskap van die boek in sy konteks te lokaliseer nie ${ }^{17}$. Wanneer Smit smalend daarvan praat dat die situasie, dit is, die konteks waarop die boek gerig was, uiteindelik vir die skrywers 'n "tower-formule" geword het "wat die probleem moet oplos", verstaan hy nie dat daar geen geldige beroep op die Skrifte mountlik is wanneer daar nie erns gemaak word met die boodskap wat die boek vir sy eerste lesers in hulle spesifieke konteks wou kommunikeer nie. Hiermee sê ek nie dat die skrywers (almal) in hierdie oogmerk geslaag of ewe goed geslaag het nie. Om in hierdie opsig te slaag is ook geen gemaklike taak nie, want om die konteks vas te stel is inderdaad problematies, en onderlinge ooreenstemming daaroor glad nie vanselfsprekend nie ${ }^{18}$. Inteendeel! As hierdie stelling die sistematikus nou hande in die lug laat gooi en met vlammende oë laat uitroep: "Willekeur" en "Verwarring" en "Modernisme", dan moet daar tog weer daaroor besin word dat dit die feitelikheid van die kanon is, dat dit die aard van die kanon self is, wat hierdie probleem in homself omdra. Die verskille oor wat die konteks van 'n boek is, is in hierdie opsig presies gelyk aan die verskille oor eksegese wat in alle kommentare aangetref word. Tog kan daar sonder om eksegetiese beslissings te maak nie gepreek word nie. Net so kan daar oor die boodskap, oor die teologie en etiek van 'n boek, nie sinvol gepraat word sonder om rekenskap te gee van en beslissings te maak oor die konteks waarop die boek gerig was nie.

\subsection{Die vraag of daar so iets soos 'n Bybelse etiek is}

Alhoewel Smit elders kla dat dit tot chaos sal lei as Nuwe-Testamentici die sistematici, etici en lidmate met 'n vrye keuse laat tussen die kontekstuele etieke van die onderskeie boeke van die Nuwe Testament ${ }^{19}$, kom hy self tot die gevolgtrekking dat dit nie goed moontlik is om van Bybelse etiek te praat nie 20 . 'n Mens moet eerder soek na die onderskeie etosse van Nuwe-Testamentiese gemeenskappe. Dit kom daarop neer dat die skrywers van die gebundelde artikels eintlik 'n ander boek moes geskryf het en dat hulle as Nuwe-Testamentici nie mooi weet wat in hulle veld aangaan nie. Die verwarring lê egter by Smit wat nie verstaan dat dit die skrywers nie om die skryf van 'n Bybelse etiek te doen is nie, maar om die analise van Bybelskrywers se etiese bedryf. 
Smit ${ }^{21}$ stel, in aansluiting by Hays, dat van Nuwe-Testamentiese etiek verwag kan word om drie take uit te voer, te wete 'n beskrywende (wat al die skrywers in die bundel doen), ' $n$ sintetiese (wat nie in die bundel voorkom nie), en 'n hermeneutiese (wat slegs deur sommiges onderneem word, maar totaal ontoereikend - dit was in die lig van die ontbreking van stap twee 'n onmoontlike taak).

Wat die "tweede taak" betref, eers net 'n opmerking. Sintese kan uiteraard nie net opgaan in "sintetiserende patrone, beelde, grammatikale spreek- en gedragsreëls, of wat ook al"22, wat uit al die geskrifte van die Nuwe Testament saamgestel is nie. Wie soek na elemente van die etiese in die onderskeie boeke, na etiese perspektiewe in die boeke van die Nuwe Testament, kan nie anders as om aandag te gee aan 'n sintese van hierdie elemente, byvoorbeeld in terme van norme, van etiese argumente, en dergelike nie. Is Smit van mening dat ook hiervan niks tereg kom in die bundel nie? Maar, in die lig van sy uitspraak: "wie in staat is om te sê wat die Bybel - of erger nog: slegs 'n bepaalde boek in die Bybel...- sê, het daarmee vir die etiek eintlik nog niks gesê nie"23, is Smit miskien nie in so 'n poginkie geïnteresseerd nie. Dan moet hier egter onthou word dat die skrywers geensins bedoel het on 'n etiek te skryf nie!

Wat in die sug na 'n onontbeerlike sintese van alle Nuwe-Testamentiese gegewens (terloops, waarom dan nie van die hele kanon en al die ander geskrifte wat vir die lewe van die vroeë kerk belangrik was nie?) nie begryp word nie, is dat die boeke van die kanon tog nooit tot stand gekom het vanuit 'n vasstaande bron van etiese patrone, beelde, of wat ook al nie. Ons het hier met tekste te doen waarvan die gesagvolheid waarmee dit praat, wel veel later erken is, maar wat in die totstandkoming daarvan pragmaties gefunksioneer het in 'n spesifieke konteks waarvoor dit geskryf was en waarvoor dit iets te sê gehad het. Wie vandag oortuig is dat so 'n teks gesag dra vir die kerk en vir moderne Christene, kan aan die pragmatiese funksie van die teks nie verbygaan sonder om dit in sy wese aan te tas nie.

Om terug te keer tot die ontbreking van 'n sintese van die Nuwe-Testamentiese gegewens - die uiteindelike belang van so 'n onderneming kan nie ontken word nie. Om dit egter van die skrywers van die bundel te verwag, of selfs dat die redaksie iemand moes gevra het om dit te doen, lê eenvoudig buite die perke van die moontlike. Smit is reg wanneer hy suggereer dat die skrywers onderling kritiek op mekaar se benaderings sou hêt $\hat{e}^{24}$. Veel meer pogings om die boeke van die Nuwe Testament vanuit hulle konteks oor hulle teologie en etiek te bevra, gaan nodig wees voordat daar vanuit hierdie perspektief sinvol aan 'n sintese gewerk kan word. In hierdie sin is Smit reg wanneer hy oordeel dat die bundel wesenlik ' $n$ binnegesprek tussen Nuwe-Testamentici verteenwoordig, maar dan tog 'n gesprek waarvan ons sou kon hoop dat daar iets uitkristalliseer van 'n manier van omgaan met die Skrifte wat aan hulle boodskap reliëf verleen en aan rykdom en toegespitste nuansering laat wen.

\section{$2.4 \quad$ Die vraag na wat die Bybel leer}

Hierdie punt hang saam met verskeie sake wat hierbo reeds aandag geniet het, maar word afsonderlik behandel omdat dit die kwessie van Skrifberoep en dié van eenheid en verskeidenheid in die teologie en etiek van die Nuwe Testament aan die 
orde stel. Om aan die skrywers duidelik te maak dat 'n beroep op die Bybel alleen nie genoegsaam is om tot geldige etiese besluitneming te voer nie, verwys $\mathrm{Smit}^{25}$ na die debat in die Gereformeerde Ekumeniese Raad, waarin daar heftig verskil is oor die reg of verkeerd van homofilie - met albei groepe wat hulle vir hulle standpunt op die Skrif beroep. Eksegese help dan ook nie om die ander te oortuig nie, want ander faktore as die Bybelteks het reeds by die oortuiging wat ontstaan het, beslissend ingewerk. Toegegee dat hierdie feite korrek is. Wat sê dit dan oor die wyse waarop Skrifberoepe geskied? Sê dit nie juis dat daar fout is met die manier waarop dié etici hulle op die Skrif beroep nie? Ook hier geld dit dat elke "ketter" sy letter het. Feit is, die Bybel "leer" nie so nie.

Juis op hierdie punt probeer Nuwe-Testamentici om te sê dat 'n geldige Skrifberoep nie op grond van die lees van 'n Bybelvers of selfs 'n perikoop gemaak kan word nie. Die teks wat 'n kommunikasie wou oordra, wat in 'n bepaalde situasie 'n verandering te weeg wou bring, was die boek as geheel wat vir daardie situasie geskryf is. Die beroep moet dus uitgaan van die boek as geheel, maar dan word dit uiters prekêr om van enige moderne situasie af - hoe goed dan ook geanaliseer - te probeer terugwerk na die Bybelse gegewens. Vandaar, meen ek, die poging van hierdie outeurs om die boeke en hulle boodskap op die vlak van die etiese aan die orde te stel. Daarmee is ten minste dit wat die teks aan sy bedoelde lesers in hulle situasie wou oordra deur een vakman na sy insig ontleed en miskien gepoog om aan te toon hoe dit ook in die moderne tyd sou kon kommunikeer. En ... is dit vir etici diensbaar as Skrifberoep, dan goed. Is dit vir hulle in hulle vraagstelling van geen waarde nie, en ook geen ander studies van dieselfde aard oor die boeke van die Bybel nie, dan is daar in hierdie geval klaarblyklik geen "hulp" van Nuwe-Testamentici beskikbaar vir 'n geldige Skrifberoep nie.

Wanneer Smit in antwoord hierop die ban van modernisme oor die skrywers uitspreek en hom beroep op die nuwe teorieë oor "die konstruktiewe rol van verskillende lesersgemeenskappe" en die "Wirkungsgeschichte" van die teks ${ }^{26}$, sou 'n mens moet vra "watter lesers"?, en "watter deel van die 'Wirkungsgeschichte""?, en "wie bepaal die legitimiteit van dié lees"?, en "wat het nou van willekeurigheid geword"?

As hy pleit dat die kanon ernstig geneem moet word omdat dit die lewensboek van die kerk is, moet hy as teoloog tog weet dat die kanon van die Nuwe Testament uit sewe-en-twintig boeke bestaan wat doodgewoon nie sewe-en-twintig hoofstukke of afdelings van 'n monografie uitmaak nie. Dat die Bybel oor bepaalde sake dinge leer, staan buite kyf. Daarom is daar vanselfsprekend 'n plek en 'n noodsaaklikheid vir sintese en die soeke na eenheid in die Bybelse boodskap oor die verskeidenheid heen. 'n Sintese oor wat (in ons geval) die Nuwe Testament oor etiese vraagstukke leer, is egter onlosmaaklik verbind aan die etiek van skrywers wat doelbewus gepoog het om die etos van hulle lesers deur hulle geskrifte te verander. Hierdie kyk op die wyse waarop die Skrifte boodskap, het natuurlik met modernisme niks te make nie. Dit het te doen met die erkenning van die eie aard van die Nuwe Testament en die wyse waarop dit ontstaan het ${ }^{27}$. PAULUS IN DIE BRIEF AAN FILEMON

Dat Paulus in Filemon eties besig is, is duidelik: dit reflekteer bewuste nadenke oor 
die morele vraagstuk van die verhouding tussen baas en slaaf, en wil in dié opsig 'n verandering teweeg bring in die etos van 'n bepaalde kerklike gemeenskap as onderdeel van die Romeins-Hellenistiese maatskappy. Die versoek wat Paulus in hierdie verband aan Filemon rig, word met 'n hele spektrum van etiese argumente onderskraag. Tog word daar, afgesien van die slawekwessie self, weinig aandag aan die etiek van Filemon geskenk, omdat die probleem van die brief so spesifiek is. Schrage ${ }^{28}$ sê dan ook dat die brief vir die kerk geen verdere toepassingsmoontlikhede bevat nie - 'n standpunt wat na my mening nie korrek is nie. Hiervoor is die teologiese onderbou van die versoek en die etiese argumente wat ten gunste van die uitvoering daarvan aangelê word, eenvoudig te diepgaande en gevarieerd.

Laat my, sonder om nou weer alles oorhoop te haal wat ek vroeër hieroor geskryf het, net kortliks saamvat waarmee ons in die brief aan Filemon te doen het en dan daarna aandag gee aan die versoek van Paulus vanuit die hoek van etiese argumentasie.

\subsection{Waaroor dit gaan in Filemon}

Anders as wat soms beweer word, is Filemon nie 'n aanbevelingsbrief nie, maar vorm die hoofdeel van die brief 'n tipiese versoekskrif waarvan die onderdele bestaan uit 'n outoriteitsaanspraak (8-9), die versoekwerkwoorde (9-10), die agtergrond (10), die verdienstelikheid van die geval (11-16), en die verlangde aksie dit is, die versoek self (17-22) ${ }^{29}$. In die geval van Filemon speel egter nie net die briefliggaam en sy vorm 'n rol in die verstaan van die versoek nie, maar ook die omramende briefaanhef (1-3) en briefslot (23-25), sowel as die gekombineerde danksegging/gebedsgedeelte (4-6) en die selfstandige oorgangsperikoop met Paulus se persoonlike uiting van blydskap oor Filemon se liefdesoptrede wat so verkwikkend inwerk op die gelowiges (7) - wat almal motiewe bevat wat retories van groot belang is vir die versoek wat gestel word.

Intussen is dit gebode by die poging om sowel die teologie as die etiek van Filemon te beskryf ${ }^{30}$, eers te vra na die situasie of konteks waarvoor die brief geskryf is. Die argumente van nuwere pogings om aan Onesimus te dink as 'n slaaf wat deur Filemon na Paulus gestuur is om hom van diens te wees, hou nie stand nie. Ongetwyfeld het ons hier met ' $n$ wegloperslaaf te doen wat op die een of ander manier by Paulus in sy gevangeniskap uitgekom het en nou deur hom na sy baas teruggestuur word soos hy moreel en wetlik verplig was om te doen ${ }^{31}$. Rondom hierdie konteks rig Paulus nou die versoek dat Filemon Onesimus sal verwelkom soos hy vir Paulus sou verwelkom het as hy self by hom op besoek sou kom $(17,22)$ 'n versoek met geweldige implikasies vir onderlinge Christelike verhoudings en vir die lewe en werk van die kerk.

Die motiverings vir hierdie versoek is velerlei en kan op verskillende maniere aan die orde gestel word. 'n Mens sou kon uitgaan van die indikatiefimperatief motief wat tipies Paulinies is en hier funksioneer in die heilsgegewenheid van God se gunsbewys wat hom in die Messiaanse vredestoesegging uit en die geloof, die vertroue op die Christus as teenhanger het. Die heilsgegewenheid is ook daarin te lees dat beide Filemon en Onesimus die heil deelagtig geword het in die verwekking tot kindskap $(10,19)$. Omdat die heil beleef is, is God se volk as gemeenskap van diens en liefde saamgesnoer (1-2. 5-6, 11-13, 23-25), sodat hulle mekaar in liefde bystaan $(5,7,9,16,20)$, gasvry is (22), en deur hulle lewe ook 
uitreik na dié wat nog buite is (6), terwyl hulle in die verhouding teenoor mekaar die broerskap as intense werklikheid beleef soos onder andere blyk uit die respek waarmee Paulus vir Filemon behandel in die stel van sy versoek $(8-9,18-19)^{32}$.

\subsection{Die versoek belig vanuit die oogpunt van etiese argumentasie}

Om die ingewikkelde prosesse van etiese besluitneming na vore te bring, het Smit ${ }^{33}$ daaraan herinner dat drie soorte etiese argumente onderskei kan word wat in die beroep op die Skrif werksaam mag wees, te wete deontologiese, teleologiese en verantwoordelikheidsargumente. Dit was vir my opvallend dat argumente of motiverings van hierdie aard, dit wil sê, van al drie die soorte, in Filemon aangetref word - uiteraard nie in die vorm van Skrifberoep nie, maar om die retoriese doel te dien. Hierby kan nog 'n vierde soort, naamlik 'n praktiese argument gevoeg word.

Word die oop situasie rondom die versoek in die oog gehou, die feit dat hier nie beveel word nie, maar 'n versoek gerig word; die feit dat die versoek opgevolg word met die oortuiging dat Filemon meer sal doen as wat Paulus vra, sonder dat gespesifiseer word wat dit sou moes behels, maar met daarin opgesluit die suggestie dat Onesimus vrygelaat sou kon word (21); die feit dat Paulus Filemon respekteer in sy besluitneming - selfs ouk tot in sy bereidheid om enige moontlike skuld te vereffen - dui alles daarop dat hy 'n beroep doen op die verantwoordelikheid van Filemon om in die nuwe situasie wat hom nou voordoen, reg op te tree.

Op die deontologiese vlak figureer die indikatief - imperatief verhouding. Die heil wat gemeenskaplik beleef is en hom uit in die gemeenskaplike ervaring van 'n lotsgemeenskap van onderlinge belangstelling en hulpverlening, van dienslewering in die liefde, word tot norm vir die optrede van een lid met hoë sosiale status teenoor ' $n$ ander op die laagste rang van die leer. Die feit dat baas en slaaf albei gelowiges geword het, saam tot die Godsvolk gaan behoort het, saam ingelyf is in die liggaam van Christus, word die beginsel waarvolgens die onderlinge verhouding van baas en slaaf sou moet opereer: in die kerk is die slaaf vry, is hy gelyk en behoort daarom as broer geaksepteer te word met al die konsekwensies hieraan verbonde.

Die teleologiese argument funksioneer in die veld van die missionêre. Die brief is in die sendingsituasie gesitueer, met Paulus in gevangenskap vanweë sy opdrag, met Filemon en Onesimus wat as resultaat van die missie kinders van God en broers van mekaar en die ander gelowiges geword het. Vanuit hierdie agtergrond word die gebed in vers 6 uitgebou om by voorbaat as argument te dien vir die toestaan van Paulus se versoek: sy bede is dat ander aan die geloofsvertroue van Filemon 'n aandeel sal verkry, met ander woorde, dat hulle net soos hy sal begin vertrou op Jesus die Gesalfde, wanneer hulle deur sy optrede (soos later blyk teenoor Onesimus) sien watter goeie dinge daar met die oog op Christus onder Christene vir mekaar gedoen word. Paulus se sending lê op die gesigseinder as doelwit wat deur Filemon se nakoming van Paulus se versoek gedien gaan word (vgl ook vers 13 ).

Selfs 'n heel praktiese argument word ook deur Paulus nie ontsien om Filemon tot sy versoek oor te haal nie. Vers 11 praat van Onesimus as 'n nikswerd wat nou baie werd geword het. Eers het hy nie veel beteken nie, maar nou is hy vir sowel Paulus as vir Filemon baie waardevol - en dus werd om goed behandel te word. Ook hierdie gegewe is egter nie los van die heilskonnotasie te verstaan nie: 
dit is die heil wat God in Onesimus bewerk het, wat van hom op die humane vlak ook 'n beter mens gemaak het.

\section{TEOI OGIE EN ETIEK IN FILEMON}

Dit behoort uit die voorafgaande oorduidelik te wees dat in Filemon teologie en etiek op mekaar afgestem is, dat die indikatief die grondslag vir die imperatief vorm, dat die heil wat God in Christus vir sy ekklesia, sy volk, bewerk het, die grondslag vorm vir die nuwe verhoudings wat in die kerk tot stand gebring is en in die praktyk van die kerklike lewe uitgeleef behoort te word. Dit is van die grootste belang vir die verstaan van Filemon dat die vermelding van die huisgemeente in vers 2 ten volle ernstig geneem sal word. Hoe Filemon teenoor sy slaaf gaan optree, is nie maar bloot 'n privaat aangeleentheid nie, maar is 'n kerklike saak - die saak van die gemeenskap van God se mense wat leef onder sy heil.

Dit is nou verder die vraag of die brief aan Filemon ook 'n betekenis het wat verder reik as die kerklike gemeenskap. Elders ${ }^{34}$ het ek geargumenteer dat dit onvermydelik die geval is. Wat hierbo aan die lig getree het, is dat vryheid, gelykheid en broerskap in die kerk ook die eis van die evangelie aan die kerk is daarin dat die kerk God se gemeenskap is waarin die evangelie kragtig gewerk het om ou waardes en verhoudings totaal te omvorm. Vir Filemon kom die versoek om in ooreenstemming hiermee op te tree egter in 'n baie genuanseerde vorm. In 'n maatskappy waarin 'n wegloperslaaf die ergste straf te wagte kon wees, word hy gevra om sy weggeloopte slaaf nou aan huis te verwelkom soos hy die eerbiedwaardige Paulus vir wie hy immers sy gastekamer gereed sou maak, sou verwelkom het as dié by hom op besoek sou kom. Die nuwe verhouding van broerskap tussen gelykes wat ewe vry is in Christus, word hier 'n beginsel wat op die sosiale vlak opereer. Wat die brief aan Filemon hier sê, is dat dit tog nie moontlik is dat Christene in die erediens vrye en gelyke broers kan wees, maar in die sosiale praktyk van die daaglikse lewe voortgaan om in die ou verhoudingsposisies te leef nie. Hiermee tree die evangelie oor die grense van die kerklike gemeenskap heen om as God se maatskappy-omvormende krag in die wêreld werksaam te wees. Juis dit mak van die kerk, as die draer vari die evangelie, God se instansie van vernuwing wat in die maatskappy sal werk vir die waardes van die evangelie.

\section{NOTAS:}

1 Referaat gelewer by die opening van die Fakulteit Teologie (Nederduitse Gereformeerde Kerk), op 1993-02-03.

2 J H Roberts, Die brief aun Filemon, Kaapstad 1992.

3 Uitgegee in 'n spesiale uitgawe van Scriptura vol S9a (1992).

4 Dirkic Smit, "Oor 'Nuwe-Testamentiese etiek', Die Christelike lewe en SuidAfrika vandag", Scriptura vol S9a (1992), 303-325.

5 Vir 'n uitstekende oorsig oor hierdie geskiedenis vide H Boers, What is New Testament theology?, Philadelphia 1979. 
6 Wat die huidige Suid-Afrikaanse situasie betref, meen Smit, Scriptura vol S9a (1992), 322, dat Nuwe-Testamentici (die skrywers in bogenoemde bydraes oor die etiek van die Nuwe Testament, vgl voetnoot 3 ) sistematici/etici "nie ernstig as gespreksgenote" neem nie.

7 Herman Ridderbos, "De Canon van het Nieuwe Testament", Kerk en Theologie vol 9 (1958), 81-95, t.s. 81-82.

8 Smit, Scriptura vol S9a (1992), 325.

9 Vergelyk in hierdie verband J H Roberts, "Struktuur en betekenis van Filemon", Theologia Evangelica vol 16/3 (1983), 59-70; "Die brief aan Filemon: Bevryding en Christelike verantwoordelikheid", Theologia Evangelica vol 18/3 (1985), 19-26; "Filemon in diskussie: Enkele hoogtepunte in die stand van sake", Scriptura vol 21 (1987), 24-50; "Navorsingsberig: 'n Kommentaar, Filemon en Kolossense", Theologia Evangelica vol 22/3 (1989), 14-20; "Vryheid, gelykheid en broederskap in die brief aan Filemon", Scriptura vol S9a (1992), 241-258.

10 Scriptura vol S9a (1992), 303-317.

11 Scriptura vol S9a (1992), 303-305.

12 Scriptura vol S9a (1992), 306,317.

13 Scriptura vol S9a (1992), 317.

14 Scriptura vol S9a (1992), 317.

15 Scriptura vol S9a (1992), 322.

16 Hierdie taak hoort tipies by dissiplines soos die etiek en die praktiese teologie.

17 Smit, Scriptura vol S9a (1992), 319, erken dat die skrywers nie probeer om direk te werk met etiese gegewens in 'n boek nie, maar sê dan $\operatorname{tog}(a w, 321)$ : "Daar word - telkemale - feitlik probleemloos beweeg van 'analoë historiese situasies' tussen die betrokke geskrif en die huidige Suid-Afrika".

18 Tussen my en Pelser gaap daar byvoorbeeld 'n onoorbrugbare kloof oor die vraag na die konteks van Efesiërs.

19 Scriptura vol S9a (1992), 320.

20 Scriptura vol S9a (1992), 314-315.

21 Vergelyk Smit, Scriptura vol S9a (1992), 318-323.

22 Scriptura vol S9a (1992), 320.

23 Scriptura vol S9a (1992), 317. 
24 Scriptura vol S9a (1992), 319.

25 Smit, Scriptura vol S9a (1992), 308-312.

26 Scriptura vol S9a (1992), 323-324.

27 Smit, Scriptura vol S9a (1992), 323, se pleitrede dat Suid-Afrikaanse NuweTestamentici ernstig daaroor moet besin dat hulle fout is om vakwetenskaplik te skryf omdat die kerke die plek is waar die Nuwe Testament ernstig geneem word en hulle dus algemeen verstaanbaar behoort te skryt, behoort eintlik onbeantwoord gelaat te word. Nuwe-Testamentici doen hulle deel aan popularisering in hierdie land.

28 W Schrage, Ethik des Neuen Testaments, Göttingen 1982, 181. Vergelyk die bespreking by Roberts, Theologia Evangelica vol 22/3 (1989), 16-17.

29 Vergelyk Roberts, Die brief aan Filemon, 1992, 46-47.

30 Vir 'n samevatting van die teologiese en etiese elemente, sien Roberts, Die brief aan Filemon, 1992, 91-93, asook die besprekings aan die einde van elke perikoop. 'n Omvangryke bespreking is voor hande in P J Gräbe, "Ontvang jou slaaf soos 'n broer! Die etiese reikwydte en ekklesiologiese implikasies van die verbondenheid aan Jesus Christus", in Teologie in konteks (Onder redaksie van J H Roberts, W S Vorster, J N Vorster, \& J G Van der Watt), Halfway House 1991, 427-439; asook Roberts, Scriptura vol S9a (1992), 241258.

31 Sien in die verband Roberts, Die brief aan Filemon, 1992, 17-19; 60-61.

32 Vergelyk Roberts, Scriptura vol S9a (1992), 250-252.

33 Scriptura vol S9a (1992), 316.

34 Roberts, Scriptura vol S9a (1992), 255-256. 